\title{
Effects of N:P:Si ratios and zooplankton grazing on phytoplankton communities in the northern Adriatic Sea. II. Phytoplankton species composition
}

\author{
Per Carlsson*, Edna Granéli
}

University of Kalmar, Department of Marine Sciences, POB 905, S-391 29 Kalmar, Sweden

\begin{abstract}
Development of phytoplankton biomass and species composition in northern Adriatic Sea natural plankton communities was investigated in 2 spring/summer (May and June) enclosure experiments. The enclosures $(100 \mathrm{l}$ plastic cylinders) were subjected to different concentrations/ratios of nitrate, phosphate and silicate in order to obtain a situation where one of these nutrients would limit phytoplankton biomass in different treatments. The initial phytoplankton community in both experiments was dominated by small (both by cell numbers and biomass) autotrophic flagellates. In the May experiment the small autotrophic flagellates made up more than $50 \%$ of the initial biomass; this was $95 \%$ in June. The duration of the experiments were 7 and $10 \mathrm{~d}$, respectively. A surplus of nitrogen, phosphorus and silicon favored the development of some fast-growing diatoms. Phosphorus deficiency induced higher phytoplankton biomass than expected from Redfield ratios (Redfield 1958), probably due to fast recycling of phosphorus compared to nitrogen. Despite low silicon concentrations in the silicon-deficient treatments, growth of diatoms was high in the May experiment suggesting a low silicon demand for the dominating small diatom species. The diatom Rhizosolenia fragilissima was particularly favored under phosphorus-deficient conditions whereas under nitrogen deficiency another diatom (Chaetoceros sp.) increased in biomass. Small flagellates were favored by either nitrogen deficiency (May) or by silicon deficiency (June). The increasing dominance of small flagellates in the natural communities during the transition from spring to summer, together with decreasing concentration of inorganic nitrogen, indicates that shortage of inorganic nitrogen can be important for the structure of northern Adriatic phytoplankton communities in this period.
\end{abstract}

KEY WORDS: Adriatic Sea Phytoplankton species composition · Diatoms - Flagellates

\section{INTRODUCTION}

The composition of phytoplankton communities continuosly changes such that different species become abundant at different times. This process of continuous community reorganization is often termed 'succession' (Smayda 1980). The succession of phytoplankton communities is often quite predictable so the same species dominate in the same waters at the same time year after year (Edler 1979b, Smayda 1980). However,

\footnotetext{
•E-mail: per.carlsson@ng.hik.se
}

sometimes species that have previously been missing or present in very low numbers can unexpectedly develop high abundance and form a bloom. The succession of phytoplankton may be caused by changing physical, chemical or biological factors such as grazing by zooplankton. Nutrient availability and the competitive ability of different phytoplankton species to utilize nutrients at low concentrations are considered to be important factors leading to succession (Tilman 1977. Sommer 1983). Others suggest, however, that competition for nutrients seldom occurs, since the planktonic system could be considered as being in a non-equilibrium state (Harris 1986). 
For most marine coastal waters and inland seas nitrogen $(N)$ is found to be the nutrient which increases phytoplankton biomass when added in bioassay experiments (Ryther \& Dunstan 1971, Howarth 1988, Granéli et al. 1990, Oviatt et al. 1995). A few cases have been reported where phosphorus (P) has been found to limit phytoplankton production (Berland et al. 1980, Smith 1984). Phosphorus has been suggested to be limiting in marine coastal waters only when large nutrient loads with high N:P ratios reach coastal waters (Howarth 1988). Phosphorus has been suggested to be the most limiting nutrient for phytoplankton primary production in the northern Adriatic Sea, since bioassay experiments have shown a marked stimulation of phytoplankton growth when $\mathrm{P}$ was added (Pojed \& Kveder 1977, Mingazzini et al. 1992). In addition, $80 \%$ of inorganic N:P ratios found in the surface waters suggests that $P$ is limiting phytoplankton growth (Chiaudani et al. 1980).

Due to the higher $\mathrm{N}$ and $\mathrm{P}$ input to coastal areas, the ratios for $\mathrm{N}$ and $\mathrm{P}$ in relation to silicon (Si) can be higher than normal in coastal waters (Wulff \& Rahm 1988, Sandén et al. 1991). A higher availability of $N$ and $P$ in coastal waters would cause the utilization of more $\mathrm{Si}$, decreasing the concentration of $\mathrm{Si}$ in the water. This has been found to occur in the Baltic Sea for over 20 yr (Wulff \& Rahm 1988). Thus, in coastal areas receiving a large input of $N$ and $P$, such as the northern Adriatic Sea, a situation may develop where $\mathrm{Si}$ is in shortage compared to available $\mathrm{N}$ and $\mathrm{P}$, and this can lead to a succession from diatoms to non-Sirequiring flagellates (Schelske \& Stoermer 1972, Smayda 1990, Conley \& Malone 1992, Egge \& Aksnes 1992).

Two enclosure experiments were performed to study how different ratios/concentrations of $\mathrm{N}, \mathrm{P}$ and $\mathrm{Si}$ affected phytoplankton biomass and species composition in natural phytoplankton communities from the northern Adriatic Sea. In the experiments we also studied the chemical composition and polysaccharide production by the phytoplankton and these results are presented in Granéli et al. (1999).

\section{METHODS}

During 14 to 21 June 1993 and 7 to 16 May 1994, land-based enclosure experiments were performed with northern Adriatic seawater. The construction of this land-based enclosure system is described in Olsson et al. (1992) and Granéli et al. (1999). The water containing the natural phytoplankton communities was pumped from 1 to $2 \mathrm{~m}$ depth from a station $15 \mathrm{~km}$ off the east coast of northern Italy, and filtered through a $100 \mathrm{um}$ mesh size nylon net in order to remove meso- zooplankton. The enclosures consisted of $100 \mathrm{l}$ white polyethylene cylinders with lids. The cylinders were immersed in a swimming pool supplied with running water in order to keep the temperature inside the cylinders close to the temperature of the surrounding sea $\left(15\right.$ to $18^{\circ} \mathrm{C}$ in May 1994,21 to $24^{\circ} \mathrm{C}$ in June 1993). The pool was covered with a black plastic net (mesh size approximately $5 \mathrm{~mm}$ ). The lids and the plastic net together decreased the light intensity by 65 to $70 \%$, and prevented photoinhibition of the phytoplankton. The light intensity (photon flux [PAR] at $20 \mathrm{~cm}$ depth) in the cylinders was very variable $(130$ to $1200 \mathrm{\mu mol}$ $\mathrm{m}^{-1} \mathrm{~s}^{-1}$ ), depending on the degree of cloudiness (measured during the primary production incubations which were performed for $2 \mathrm{~h}$ around noon).

After filling the cylinders with 100 I of seawater, samples were taken from all the cylinders for immediate analyses of nutrients $\left(\mathrm{NO}_{3}, \mathrm{NH}_{4}, \mathrm{PO}_{4}\right.$ and $\left.\mathrm{SiO}_{2}\right)$, chlorophyll a (chl a), primary production and water was filtered for later analyses of particulate organic carbon (POC), nitrogen (PON) and phosphorus (POP) (see Granéli et al. 1999). Based on the concentrations found for the different nutrients in the collected water, additions of $\mathrm{NO}_{3}, \mathrm{PO}_{4}$ and $\mathrm{SiO}_{2}$ were made to the different cylinders in order to obtain different nutrient ratios. Nutrients were added either as one initial pulse (June 1993 experiment) or as daily pulses to reach a certain concentration (May 1994 experiment) (see Granéli et al. 1999). Each treatment was performed in triplicate. Iron, EDTA and trace metals (Cu, Zn, Co, Mn and $\mathrm{Mo}$ ) were added at concentrations corresponding to $1 / 20$ of the culture medium ' $f$ ', described by Guillard \& Ryther (1962), in order to prevent any limitation of phytoplankton growth by these substances. For the same reason, vitamins (B12, biotin and thiamin) were added according to Schöne \& Schöne (1982) (as 1/20 of the original description).

The water in the cylinders was filtered once more through a $100 \mu \mathrm{m}$ nylon net after $3 \mathrm{~d}$ in the experiment during May 1994. This was done in order to remove the copepodites that had developed from nauplii/eggs that were present in the initial $100 \mu \mathrm{m}$ filtered water. This filtration procedure effectively prevented a copepod population from developing in the cylinders, as had happened in the May 1993 and June 1993 experiments (Turner et al. 1999).

Samples were taken daily for analyses of nutrients $\left(\mathrm{NO}_{3}, \mathrm{NH}_{4}, \mathrm{PO}_{4}\right.$ and $\left.\mathrm{SiO}_{2}\right)$ and chl a concentration (see Granéli et al. 1999 for details). Samples for identification and counting of phytoplankton cells were taken daily and fixed in acid Lugol's solution. Later, only the samples from the initial day and other selected days (among them, the day with the highest chl a concentration) were counted with a Nikon TMS inverted microscope using the method described by Utermöhl 
(1958). At least 50, but often more than 400, cells were counted (depending on the abundance in the samples) for each phytoplankton species/group, giving standard deviations of $\pm 28 \%$ or $\pm 10 \%$, respectively. The dimensions of at least 10 cells of each species/group were measured for calculation of plasma volume of diatoms and cell volume of other species, following stereomet-

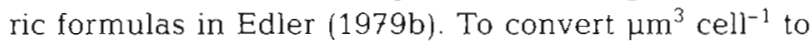
pg Cell ${ }^{-1}$, the conversion factors 0.13 for dinoflagellates (Smetacek 1975) and 0.11 for all other species were used (Strathmann 1967).

\section{RESULTS}

\section{Nutrients and chl a}

Results for nutrients and chl a are presented in detail in the previous paper (Granéli et al. 1999, in this issue).

\section{Cell carbon (determined microscopically by cell counts and calculated plasma volumes)}

Carbon content was calculated for the dominating species by measurement of the linear dimensions (Table 1). This was done in order to make a comparison of the biomass of the different species dominating under different nutrient conditions instead of just comparing cell numbers.

In May 1994, the initial phytoplankton community was dominated by small flagellates (5 to $10 \mu \mathrm{m}$ ) that made up $54 \%$ of the biomass (Fig. 1). Diatoms made up $45 \%$ of the initial biomass and dinoflagellates comprised only $1 \%$ of the initial biomass. Some species reached their maximum biomass on Day 6 of the experiment, while others increased until Day 10. On Day 6, diatoms dominated the biomass in all treatments (between 77 and $97 \%$ of the biomass). In the low-level Si-deficient treatment $\left(1 \mu\right.$ mol Si $\left.l^{-1} \mathrm{~d}^{-1}\right)$ small flagellates made up a significantly larger proportion $(23 \%)$ of the biomass than in the other treatments $(\mathrm{p}<$ 0.05 , ANOVA, Fishers PLSD). Also, in the in the $4 \mu \mathrm{mol}$ $\mathrm{Si}^{-1} \mathrm{~d}^{-1}$ treatment, the flagellates made up a high proportion of the total biomass (14\%), but not significantly higher. On Day 10, the biomass of flagellates had decreased in the Si-deficient treatments and made up only 2 to $3 \%$ of the biomass, while they still increased in the low-level $\mathrm{N}$-deficient treatment $\left(1 \mu \mathrm{mol} \mathrm{N} \mathrm{l}^{-1}\right.$ $\mathrm{d}^{-1}$ ), comprising $20 \%$ of the biomass on Day 10 , which was significantly more than in any other treatment $(\mathrm{p}<$ 0.05, ANOVA, Fishers PLSD). Dinoflagellates never made up more than $1 \%$ of the biomass during this experiment. The biomass became significantly higher $(p<0.05$, ANOVA, Fishers PLSD) in the low-P treat-
Table 1. Calculated carbon content of the dominant phytoplankton species/groups. Linear dimensions of at least 10 cells of each category were measured and cell volumes were calculated according to Edler (1979). To convert $\mu^{3}$ cell $^{-1}$ to pg $\mathrm{C}$ cell $^{-1}$, the conversion factors 0.13 for dinoflagellates (Smetacek 1975) and 0.11 for the other categories were used (Strathmann 1967)

\begin{tabular}{|lr|}
\hline & pg C cell \\
\cline { 2 - 2 } & \\
\hline June 1993 & \\
Prorocentrum micans & 1300 \\
Prorocentrum minimum & 140 \\
Protoperidinium steinii & 1900 \\
Nitzschia sp. 1 & 4 \\
Rhizosolenia fragilissima & 102 \\
Flagellates 6 to 10 $\mu \mathrm{m}$ & 35 \\
Flagellates 3 to $6 \mu \mathrm{m}$ & 4 \\
May 1994 & \\
Chaetoceros sp. & 16 \\
Nitzschia closterium & 105 \\
Nitzschia sp. 2 & 98 \\
Rhizosolenia fragilissima & 210 \\
Cyclotella sp. & 15 \\
Flagellates 5 to $10 \mu \mathrm{m}$ & 20 \\
\hline
\end{tabular}

ment $\left(0.2 \mu \mathrm{mol} \mathrm{P} \mathrm{l}^{-1} \mathrm{~d}^{-1}\right)$ (mean: $3200 \mu \mathrm{g} \mathrm{Cl}^{-1}$ ), than in

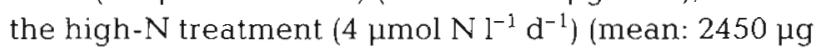
$\mathrm{C}^{-1}$ ). This was despite the fact that the daily additions of nutrients to these 2 treatments should have been almost comparable according to their ratio $(4 / 0.2=20)$, which is close to the Redfield ratio of 16 . Also, phytoplankton biomass expressed as both POC and chl a concentration was higher in the low-P treatment than in the high- $\mathrm{N}$ treatment (see Granéli et al. 1999).

In the June 1993 experiment, initial phytoplankton C was dominated by smaller ( 3 to $6 \mu \mathrm{m}$ ) flagellates, which made up $77 \%$ of the initial biomass. Larger flagellates (6 to $10 \mu \mathrm{m}$ ) comprised $18 \%$ of the initial biomass, while dinoflagellates and diatoms only accounted for $5 \%$ (Fig. 2). During the experiment, smaller flagellates still dominated the biomass but diatoms also became important and made up 20\% of the biomass in the nutrient-sufficient treatment by Day 5, when maximum biomass was attained in most of the treatments (see Granéli et al. 1999). In the June 1993 experiment, phytoplankton biomass did not become appreciably higher in the P-deficient treatment than in the N-deficient treatment. In the P-deficient treatment, the biomass of diatoms also increased and comprised $35 \%$ of the biomass on Day 5 . In the Si-deficient treatment, the smaller flagellates ( 3 to $6 \mu \mathrm{m}$ ) became totally dominant ( $75 \%$ of the biomass on Day 7 ), while diatoms only comprised $2 \%$ of the biomass in this treatment at the end of the experiment. The maximum biomass of flagellates was significantly higher in the Si-deficient treatment than in the other treatments ( $\mathrm{p}<$ 0.005, ANOVA, Fishers PLSD). 


\section{MAY 1994}
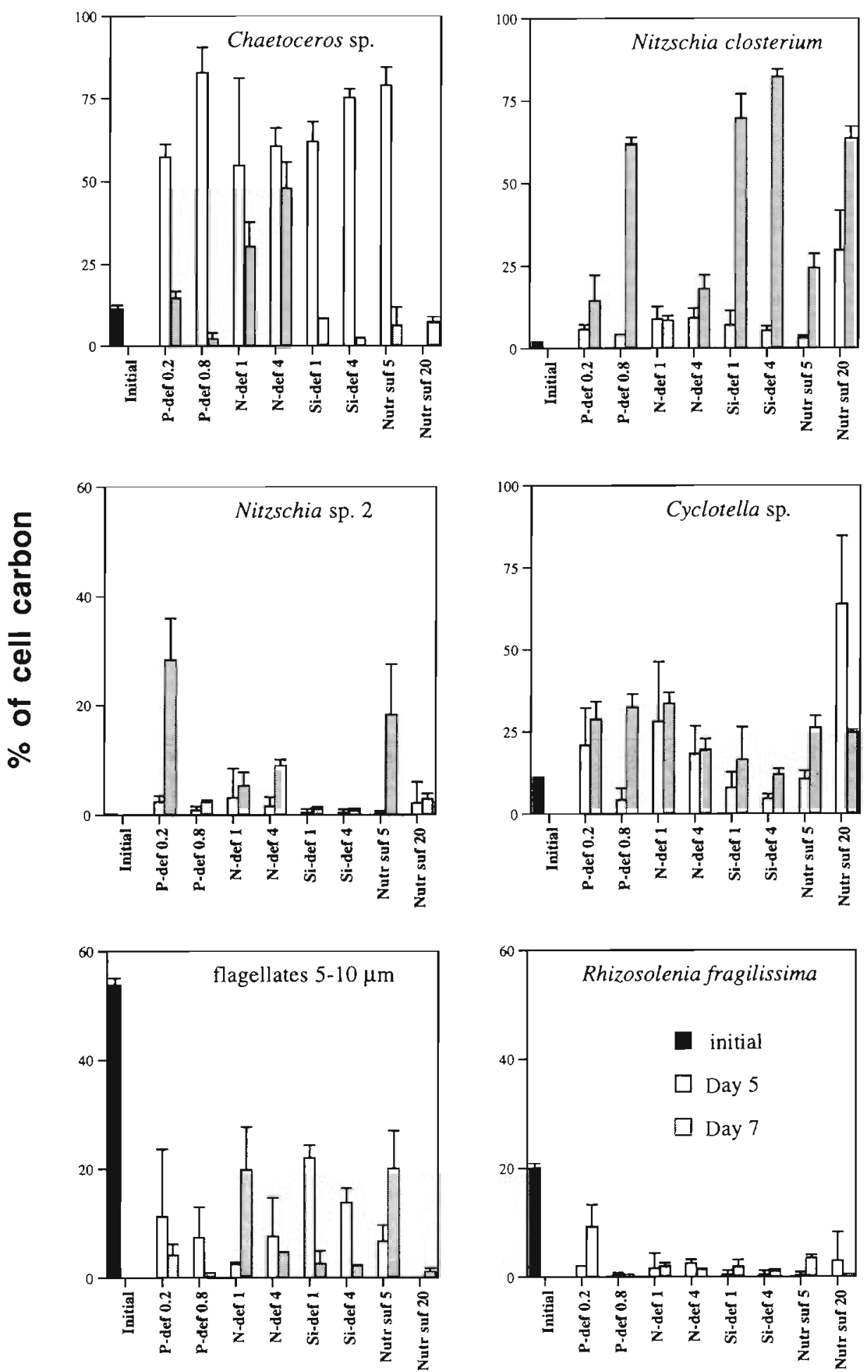

Fig. 1. Dominant phytoplankton species/groups during the May 1994 experiment (as \% of total cell carbon calculated from cell volumes). P-def 0.2: phosphorus-deficient treatment (low addition): P-def 0.8: phosphorus-deficient treatment (high addition): $\mathrm{N}$-def 1: nitrogen-deficien: treatment (low addition): $\mathrm{N}$-def 4 : nitrogen-deficient treatment (high addition): Si-def 1 : silicon-deficient treatment (low addition): Si-def 4: silicon-deficient treatment (high addition): Nutr suf 5: nutrient-sufficient treatment (low addition): Nutr suf 20: nutrient-sufficient treatment (high addition). See Granéli et al. (1999) for details on nutrient additions. (Mean $\pm \mathrm{SD}, \mathrm{n}=3$ ) 

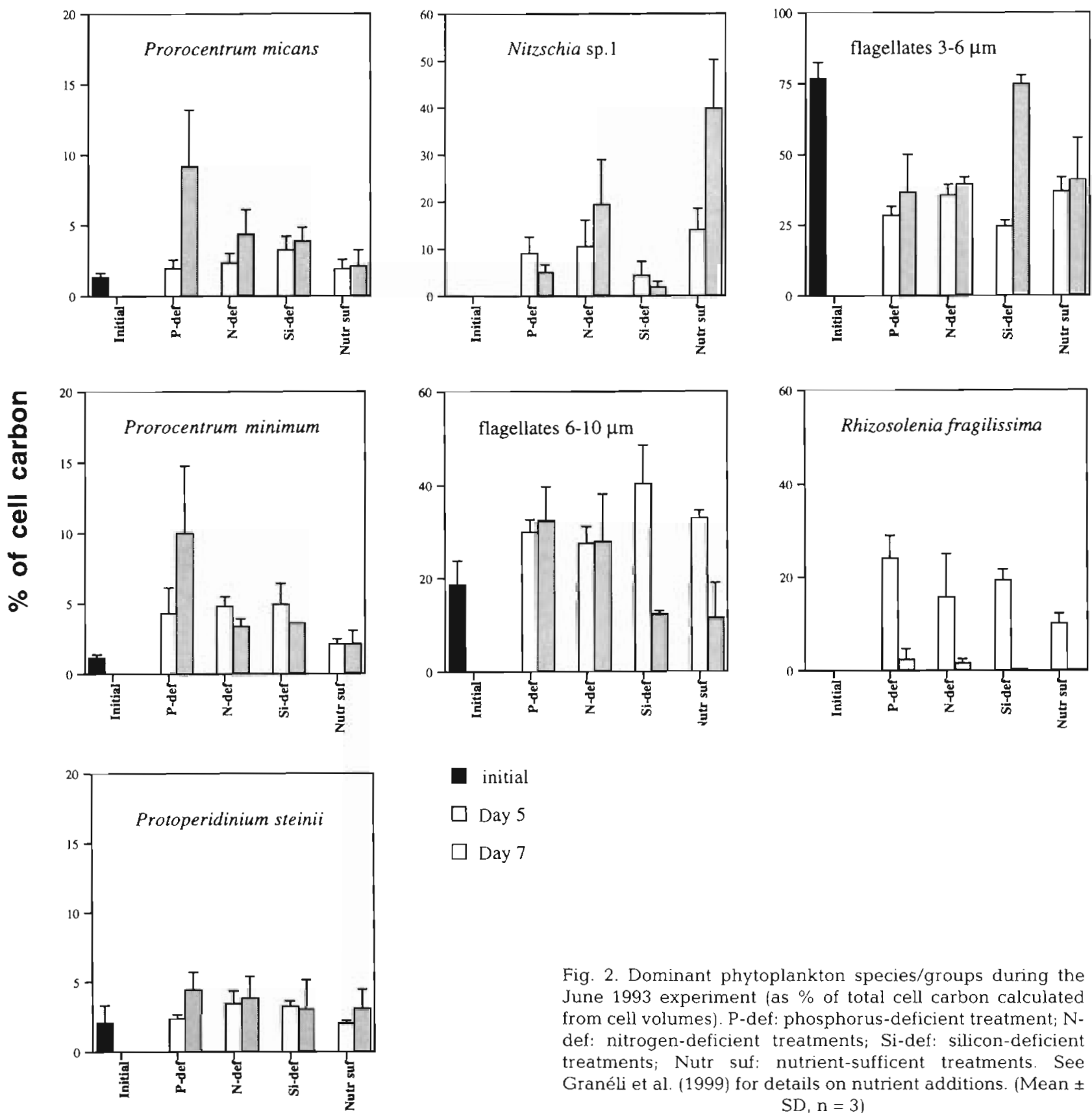

initial

$\square$ Day 5

$\square$ Day 7

\section{Phytoplankton species composition}

In the May 1994 experiment, diatoms and small flagellates were the most abundant components of the phytoplankton community. Dinoflagellates were very scarce, with $<3$ cells $\mathrm{ml}^{-1}$ of Protoperidinium steinii and $<2$ cells $\mathrm{ml}^{-1}$ of Prorocentrum micans, which were the most common dinoflagellates. Thus, dinoflagellates are not further discussed in the treatment of the May 1994 results. Initially, the community was composed of mainly small flagellates and the diatoms $R h i-$ zosolenia fragilissima, Nitzschia closterium, a small

Fig. 2. Dominant phytoplankton species/groups during the June 1993 experiment (as \% of total cell carbon calculated from cell volumes). P-def: phosphorus-deficient treatment; $\mathrm{N}$ def: nitrogen-deficient treatments; Si-def: silicon-deficient treatments; Nutr suf: nutrient-sufficent treatments. See Granéli et al. (1999) for details on nutrient additions. (Mean \pm $\mathrm{SD}, \mathrm{n}=3$ )

Cyclotella species and a small solitary Chaetoceros species (Fig. 1). In the treatments with the highest nutrient additions, $N$. closterium became dominant (more than $40 \times 10^{3}$ cells $\mathrm{ml}^{-1}$ ), except in the high- $\mathrm{N}$

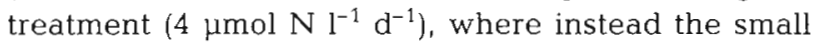
solitary Chaetoceros sp. became dominant (Fig. 3). This genus was also dominant in all the low-level nutrient-addition treatments. Small flagellates were most important in the low- $\mathrm{N}$ treatment (average $12 \times$ $10^{3}$ cells $\mathrm{ml}^{-1}$ ). In the treatment with a low addition of Si $\left(1 \mu \mathrm{mol} \mathrm{Si} \mathrm{l}^{-1} \mathrm{~d}^{-1}\right)$, Si deficiency was not apparent until the last $2 \mathrm{~d}$ of the experiment, and therefore did 
MAY 1994
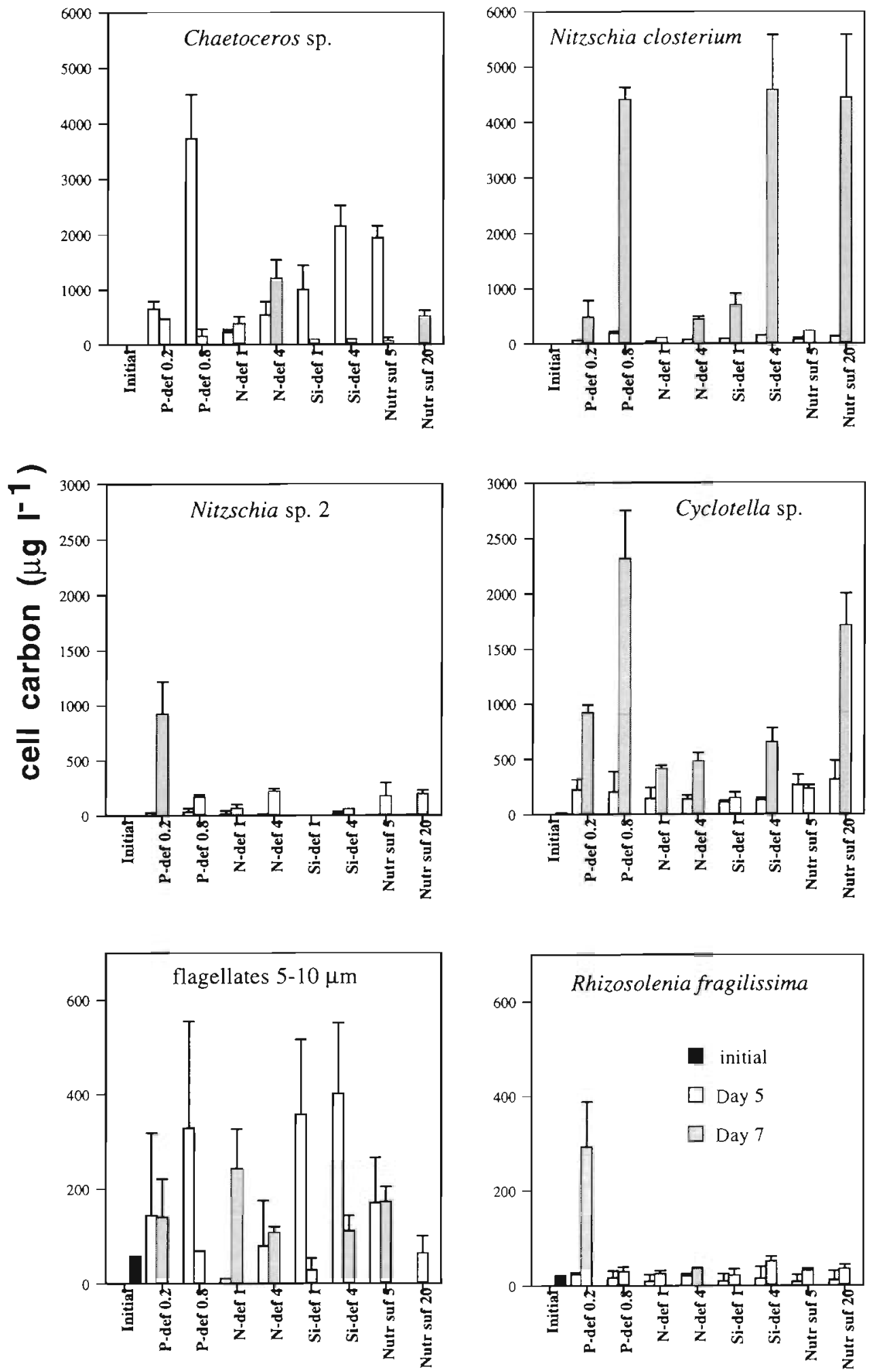

Fig. 3. Cell carbon ( $\mu \mathrm{g}^{-1}$ ) for the dominant phytoplankton species/groups during the May 1994 experiment. See Table 1 for carbon content per cell. Treatments as in Fig. 1. (Mean \pm SD, $n=3$ ) 
JUNE 1993
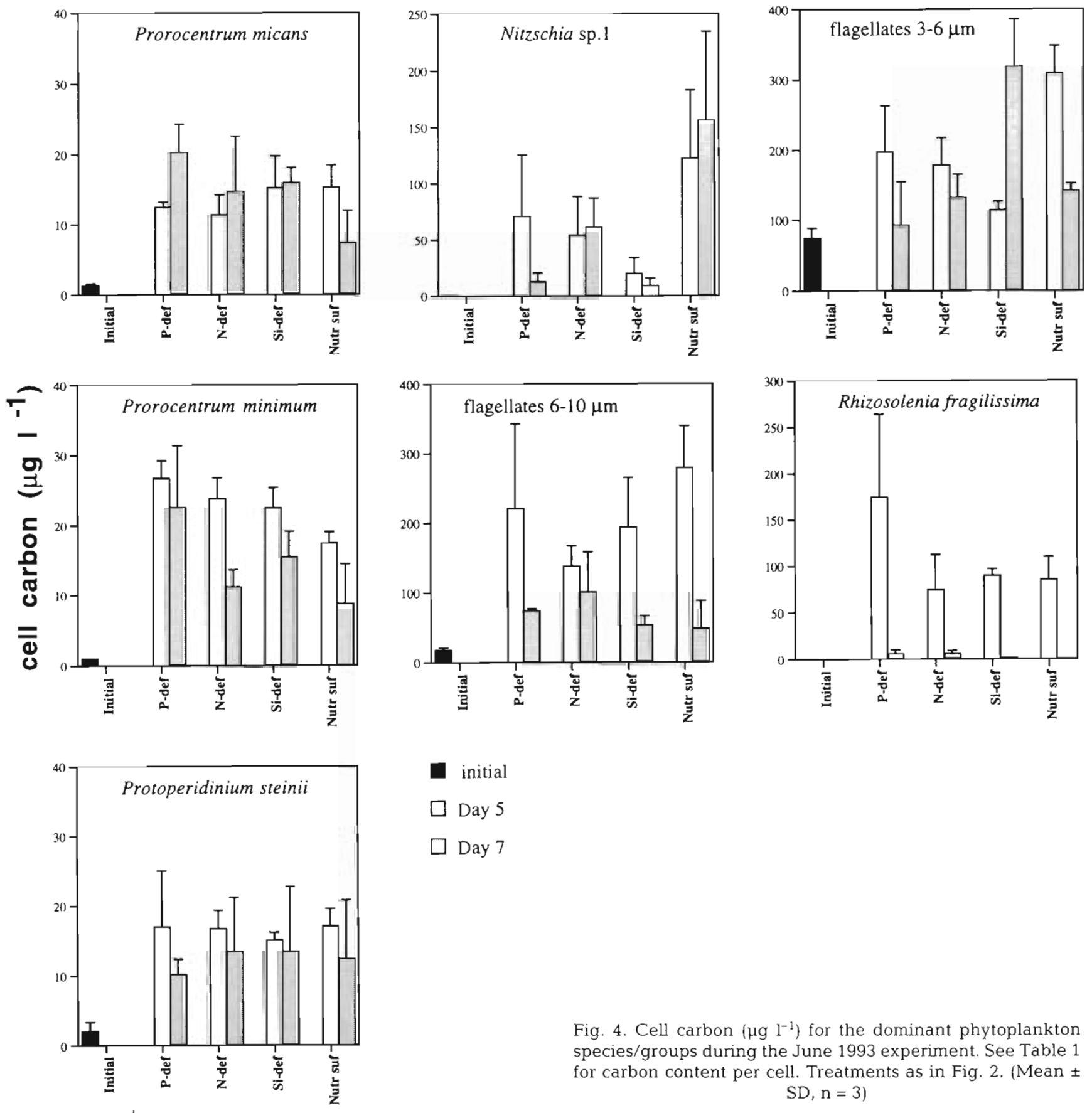

initial
$\square$ Day 5
$\square$ Day 7

not cause any significant decrease in the dominance of diatoms.

In the June 1993 experiment, small unidentified flagellates ( 3 to $6 \mu \mathrm{m}$ ) and flagellates ( 6 to $10 \mu \mathrm{m}$; cryptomonads, haptophyceans and unidentified flagellates) dominated the initial phytoplankton community, both in terms of cell numbers and carbon biomass (Fig. 2). During the experiment, dinoflagellates, such as Prorocentrum micans, $P$. minimum and Protoperidinium
Fig. 4. Cell carbon ( $\mathrm{g} \mathrm{g} \mathrm{l}^{-1}$ ) for the dominant phytoplankton species/groups during the June 1993 experiment. See Table 1 for carbon content per cell. Treatments as in Fig. 2. (Mean \pm $\mathrm{SD}, \mathrm{n}=3$ )

spp., and 2 diatom species (Nitzschia sp. 1 and Rhizosolenia fragilissima) increased in biomass (Fig. 4). At the end of the experiment, the small flagellates dominated in the Si-deficient treatment, while there were only a few diatom cells in this treatment. The diatom species increased to very high cell numbers $\left(>40 \times 10^{3}\right.$ cells $\mathrm{ml}^{-1}$ for Nitzschia sp. 1) in the nutrient-sufficent treatment. By Day 5, both $R$. fragilissima and Nitzschia sp. 1 had reached high cell numbers in the P-deficient 
treatment. In this treatment, however, the cell number of the diatoms decreased between Days 5 and 7 . The autotrophic dinoflagellate $P$. minimum also reached higher cell numbers in the P-deficient treatment than in the N-deficient treatment ( $p<0.05$, ANOVA, Fishers PLSD).

\section{Possible effects of zooplankton on phytoplankton species composition in enclosures}

During the June 1993 experiment, abundant copepod nauplii (5 to 35 nauplii $\mathrm{l}^{-1}$ ) were initially present in the cylinders, despite attempts to remove zooplankton by screening with $100 \mu \mathrm{m}$ mesh (Turner et al. 1999, in this issue). Possibly, these nauplii passed the mesh as eggs and hatched into nauplii within the first $24 \mathrm{~h}$ of incubation. By Day 4 of the experiment, the number of Acartia and Oithona copepodites in enclosures increased substantially ( 10 to 25 copepodites $\mathrm{l}^{-1}$ ). Filtration rates determined for Acartia copepodites during the 1993 experiment were either undetectable or low $\left(<0.2 \mathrm{ml}\right.$ copepod ${ }^{-1} \mathrm{~h}^{-1}$ ), possibly because phytoplankton cell numbers were extremely high, inhibiting copepod feeding (Turner et al. 1999). In order to avoid the problem with possible grazing impact on phytoplankton species succession during the experiments, the water in the cylinders was filtered a second time through $100 \mu \mathrm{m}$ mesh size nylon net after $3 \mathrm{~d}$ in the May 1994 experiment. This filtration effectively stopped any development of copepods. In view of the low grazing activity during the June 1993 experiment, and the removal of grazers by the second filtration during the May 1994 experiment, it appears that copepod feeding did not have any substantial impact upon phytoplankton species succession in either of the experiments.

\section{DISCUSSION}

The experiments show that species composition of the phytoplankton communites was significantly affected by the nutrient manipulations. The initial phytoplankton community in both experiments was dominated by small autotrophic flagellates (both in terms of cell numbers and biomass). The diatom taxa present in the initial community were similar in both experiments and the dominant diatoms were of small size (like the small solitary Chaetoceros sp. and the Cyclotella sp.) (Table 1). However, there was a clear distinction between the initial communities, with the May community having a typical spring character with more diatoms, compared with the June community, which had more species characteristic of a later suc- cessional stage (dinoflagellates and small autotrophic flagellates). This coincided with a lower concentration of inorganic $N$ in the initial water used in the June experiment compared with the May experiment (see Granéli et al. 1999).

In both experiments, diatoms from a few genera became the most abundant phytoplankton in the treatments when the small flagellates did not continue to dominate, whereas dinoflagellates were always quite scarce. One diatom species (Rhizosolenia fragilissima) was favored under P-deficient conditions in both the May 1994 and June 1993 experiments, while N deficiency allowed another diatom species (Chaetoceros sp.) to increase in biomass in the May 1994 experiment. Small flagellates were favored by either Si deficiency (June 1993) or by $\mathrm{N}$ deficiency (May 1994), and a surplus of N, P and Si enhanced the development of certain fast-growing diatoms (Nitzschia spp.) in both May 1994 and June 1993

The concentrations of the nutrients presumed to be limiting for production of phytoplankton biomass were low only during the last days of the June 1993 experiment, since nutrients had been added as a single initial pulse. This means that all phytoplankton species had access to all nutrients in surplus during the first part of this experiment, and it is therefore not surprising that there were no large differences in biomass of the different species between treatments. In the May 1994 experiment, however, the pulsed addition of small amounts of nutrients each day, instead, created a situation where the phytoplankton was subjected to low levels of a deficient nutrient over a longer time. This was also reflected in the larger differences in the final species dominance between treatments in this experiment.

Silicon concentrations never decreased below $0.55 \mu \mathrm{mol} 1^{-1}$. This was probably the amount of Si that was left when the diatoms had taken up as much of the added Si as they were able to do. At this concentration, the diatoms probably did not have maximum growth rates, even though the calculated growth rates were quite high. The pulsed addition of $\mathrm{Si}$ in the Si-deficient treatment in the 1994 experiment permitted the dominant diatoms to grow at $\mu=0.7$ to 1.0 , i.e. 1.0 to 1.4 doublings $\mathrm{d}^{-1}$. A high growth rate is also indicated by the POC:chl a ratios, which were always below 100 (Granéli et al. 1999), indicating healthy, growing cells (Goldman 1980). Reported half-saturation constants for growth of marine diatoms are in the range of 0.02 to $0.5 \mu_{\mathrm{mol}}^{-1}$ (Paasche 1980). Diatoms produce less-silicified cell walls at increasing Si deficiency, but can maintain their growth rates even at quite low Si concentrations (Paasche 1980). A smaller cell size may also be beneficial for Si assimilation at low concentrations (Paasche 1973), and the diatom species growing well 
in our enclosures can be considered as 'small' species (the solitary Chaetoceros species valve diameter was 5 to $6 \mu \mathrm{m}$ and the Cyclotella species valve diameter was approximately $3 \mu \mathrm{m}$ ). Silicon concentration in samples from northern Adriatic surface and intermediate water layers are $4.7 \pm 1.5$ and $2.6 \pm 0.9 \mathrm{mmol} \mathrm{l}^{-1}$ during summer periods (Franco \& Michelato 1992). This is considerably higher than the level of $0.55 \mu \mathrm{mol} \mathrm{r}^{-1}$ where diatoms were able to deplete silicate concentrations in the water, while still maintaining high growth rates in our experiments. It is also higher than reported half saturation constants. Thus, diatoms in these waters should not have reduced growth rates due to lack of Si.

It has been reported that marine diatom communites on average require $\mathrm{N}$ and $\mathrm{Si}$ in equal amounts (Brzezinski 1985). However, optimum Si-to-P-uptake ratios have a large range for different diatom species (from 96:1 to 1:1 for freshwater diatoms, Kilham \& Kilham 1984). Diatoms with a low Si:P demand would need very small amounts of Si compared to $\mathrm{N}$, assuming that their N:P demand is $16: 1$. It is also argued that most marine diatoms have lower demands for Si than freshwater species (Paasche 1980, Sommer 1988, Conley et al. 1989). Therefore, it is possible that in the Sideficient treatments, which received the same quantity of $\mathrm{Si}$ (moles) as $\mathrm{N}$ received in the $\mathrm{N}$ deficient treatments, the high resulting biomass of diatoms depended on the dominating diatoms having a low demand for Si compared to N (in the Si-deficient treatments, both $\mathrm{N}$ and $\mathrm{P}$ were in surplus).

A succession from diatoms to small flagellates in Siand $\mathrm{N}$-deficient enclosures has also been observed by Shölhorn \& Granéli (1996) and by Escavarage et al. (1994).

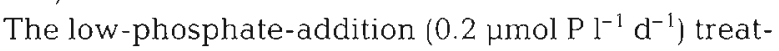
ment in the May 1994 experiment resulted in much higher maximum chl a concentrations than expected from Redfield ratios, since the biomass (as chl a) was higher (approximately double) that in the $\mathrm{N}$-deficient treatment where 4 pmol $\mathrm{l}^{-1} \mathrm{~d}^{-1}$ of nitrate was added. This could have been an effect of a faster recycling of $P$ than of $N$. Short recycling times for $\mathrm{P}(<1 \mathrm{~h}$ turnover $)$ have been measured in northern Adriatic seawater (Azam et al. unpubl.). A longer turnover time for $\mathrm{N}$ means that a substantial part of the $\mathrm{N}$ pool may be in dissolved organic form instead of in phytoplankton cells. The reason that this difference in biomass obtained between the $\mathrm{P}$ - and $\mathrm{N}$-deficient treatments did not occur in the June 1993 experiment may be that $\mathrm{N}$ or $\mathrm{P}$ were limiting phytoplankton growth during a shorter period of this experiment (see Granéli et al. 1999).

The dominance of smaller flagellates in the initial water of the experiments is likely a typical feature of Adriatic waters during this time of the year, as has been found in other Mediterranean areas (Estrada 1985). Since these smaller flagellates kept their dominance in the $\mathrm{N}$-deficient treatments in the May experiment, while diatoms became more dominant in the other treatments, the natural phytoplankton communities in the northern Adriatic Sea may well be deficient in available $\mathrm{N}$ during the summer period. Moreover, small flagellates decreased in importance in the P-deficient treatments in the May experiment and were very scarce at the end of the experiment. Our speculation that $\mathrm{N}$ could be important for the phytoplankton succession in the northern Adriatic Sea is also supported by the increasing dominance of flagellates in the spring-to-summer transition observed in the initial water used in our experiments, and by Estrada (1985) for other parts of the Mediterranean, simultaneously with decreasing concentrations of inorganic $\mathrm{N}$ in the water (see Vollenweider et al. 1992, Granéli et al. 1999).

Nitrogen and Si deficiency were the main factors limiting diatom growth in our experiments, even though growth of diatoms was also quite high in the Sideficient treatments. Small flagellates appeared to be favored by $\mathrm{N}$ deficiency, perhaps by decreased competition with diatoms in these treatments. The few autotrophic dinoflagellate species present in the June 1993 experiment (Prorocentrum micans and P. minimum) grew best in the P-deficient treatments, but never became dominant in any treatment. This suggests that the autotrophic dinoflagellates were less-competitive species than the diatoms and the small flagellates. The heterotrophic dinoflagellate Protoperidinium steinii did not show any different response to different treatments, and it grew quite well in all treatments. This could be an effect of the heterotrophic feeding mode of this species. Many Protoperidinium species have been shown to feed upon diatoms, using a pseudopod (pallium) (Gaines \& Taylor 1984, Jacobsen \& Anderson 1986), and the increase in diatoms in all treatments would have supplied the $P$. steinii cells with an unlimited food supply, irrespective of the treatment.

The ratio for the combined nitrate + ammonium to phosphate in the Adriatic Sea is usually higher than the Redfield ratio, suggesting that $\mathrm{P}$ would limit the production of phytoplankton biomass (Chiaudani \& Vighi 1982). Bioassay experiments have also shown that $\mathrm{P}$ can limit the final biomass attained by phytoplankton (Chiaudani \& Vighi 1982, Mingazzini et al. 1992). However, the rapid regeneration of phosphate in situ (Azam et al. unpubl.) may well be a factor that prevents phosphate from being in shortage during the summer in the oligotrophic part of the northern Adriatic Sea, when inorganic $N$ concentration is also low.

In summary, the results from these enclosure experiments reveal that balanced addition of nutrients 
caused the phytoplankton community to become totally dominated by fast-growing diatoms. The phytoplankton biomass (as chl a, POC: Granéli et al 1999; or as calculated cell $C$ : this paper) became considerably higher when phosphate was added than when a comparable amount (Redfield ratio) of inorganic $N$ was added. Also, small flagellates tended to grow better than diatoms at $\mathrm{N}$-deficient conditions in the May experiment. This, together with increasing dominance of small flagellates coinciding with decreasing inorganic $N$ concentrations in the initial samples from spring to summer), reported monitoring data (Vollenweider et al. 1992) and the faster recycling of $\mathrm{P}$ compared to $\mathrm{N}$ prompts us to speculate that the availability of inorganic $\mathrm{N}$ may be important for both the biomass production and species succession in the natural phytoplankton communities in the northern Adriatic Sea during the summer period when the input of new $\mathrm{N}$ to the system is limited by lower flow trom the Po River.

\section{LITERATURE CITED}

Berland BR, Bonin DJ, Maestrini SY (1980) Azote ou phosphore? Considérations sur le 'paradoxe nutritionel' de la mer méditerranée. Oceanol Acta 3:135-142

Brzezinski MA (1985) The Si:C:N ratio of marine diatoms: interspecific variability and the effect of some environmental variables. J Phycol 21:347-357

Chiaudani G, Vighi $M$ (1982) Multistep approach to identification of limiting nutrients in Northern Adriatic, eutrophied waters. Water Res 21:219-229

Chiaudani G, Gaggino GF, Vighi M (1980) Nutrient limitation assessment in Emilia-Romagna eutrophicated coastal waters. In: Workshop on pollution of the Mediterranean. Procs ICSEM/UNEP, Cagliari, p 383-390

Conley DJ, Malone TC (1992) Annual cycle of dissolved silicate in Chesapeake Bay: implications for the production and fate of phytoplankton biomass. Mar Ecol Prog Ser 81:121-1.28

Conley DJ, Kilham SS, Theriot E (1989) Difference in silica content between marine and freshwater diatoms. Limnol Oceanogr 34:205-213

Edler L (ed) (1979a) Recommendations on methods for marine biological studies in the Baltic Sea-phytoplankton and chlorophyll. The Baltic Marine Biologists, Publ no. 5, Lund

Edler L (1979b) Phytoplankton succession in the Baltic Sea. Acta Bot Fenn 110:75-78

Egge JK, Aksnes DL (1992) Silicate as regulating nutrient in phytoplankton competition. Mar Ecol Prog Ser 83:281-289

Escavarage V, Prins TC, Pouwer AJ, Haas HA. Peeters JCH (1994) Phytoplankton dynamics along phosphate gradients in mesocosms. In: Smaal AC, Peeters JCH, Haas HA, Heip CHR (eds) The impact of marine eutrophication on phytoplankton and benthic suspension feeders. Progress report I: results of mesocosm experiments with reduced $P$ load and increased grazing pressure. Royal Netherlands Academy of Arts and Sciences. Netherlands Institute of Technology Centre for Estuarine and Coastal Ecology, Den Haag, p 41-68

Estrada M (1985) Deep phytoplankton and chlorophyll maxima in the Western Mediterranean. In: Moraitou-Apostopoulou M, Kiortsis V (eds) Marine Mediterranean ecosys- terns. Plenum Press, New York, p 247-277

Franco P, Michelato A (1992) Northern Adriatic Sea: oceanography of the basin proper and of the western coastal zone. In: Vollenweider RA, Marchetti R, Viviani R (eds) Marine coastal eutrophication. Elsevier, Amsterdam, p 35-62

Gaines G, Taylor FJR (1984) Extracellular digestion in marine dinoflagellates. J Plankton Res 6:1057-1061

Goldman JC (1980) Physiological processes, nutrients availability and the concept of relative growth rate in marine phytoplankton ecology. Brookhaven Symp Biol 31:179-194

Granéli E, Wallström K, Larsson U, Granéli W, Elmgren R (1990) Nutrient limitation of primary production in the Baltic Sea area. Ambio 19:142-151

Granéli E, Carlsson P, Turner JT, Tester P, Bechemin C, Dawson $R_{r}$ Funari E (1999) Effects of N:P:Si: ratios and zooplankton grazing on phytoplankton communities in the northern Adriatic Sea. I. Nutrients, phytoplankton biomass, and polysaccharide production. Aquat Microb Ecol $18: 37-54$

Guillard RRL, Ryther JH (1962) Studies of marine planktonic diatoms I. Cyclotella nana Hustedt and Detonula confervacea (Cleve) Gran. Can J Microbiol 8:229-239

Harris GP (1986) Phytoplankton ecology - structure, function and fluctuation. Chapman and Hall, London

Howarth RW (1988) Nutrient limitation of net primary production in marine ecosystems. Ann Rev Ecol 19:89-110

Jacobson DM, Anderson DM (1986) Thecate heterotrophic dinoflagellates: feeding behaviour and mechanisms J Phycol 22:249-258

Kilham SS, Kilham P (1984) The importance of resource supply rates in determining phytoplankton structure. In: Meyers DG, Strickler JR (eds) Trophic interactions within aquatic ecosystems. Am Assoc Adv Sci Select Symp Ser $85: 7-28$

Mingazzini M, Rinaldi A, Montanari G (1992) Multi-level nutrient enrichment bioassays on Northern Adriatic coastal waters. In: Vollenweider RA, Marchetti R, Viviani $R$ (eds) Marine coastal eutrophication. Elsevier, Amsterdam, p 115-131

Olsson P, Granéli E, Carlsson P, Abrev P (1992) Structuring of a postspring phytoplankton community by manipulation of trophic interactions. J Exp Mar Biol Ecol 158:249-266

Oviatt C, Doering P, Nowicki B, Reed L, Cole J, Frithsen J (1995) An ecosystem level experiment on nutrient limitation in temperate coastal marine environments. Mar Ecol Prog Ser 116:171-179

Paasche E (1973) Silicon and the ecology of marine plankton diatoms. II Silicate-uptake kinetics in five diatom species. Mar Biol 19:262-269

Paasche E (1980) Silicon. In: Morris I (ed) The physiological ecology of phytoplankton. Blackwell, Oxford, p 259-284

Pojed I, Kveder S (1977) Investigation of nutrient limitation of phytoplankton production in the North Adriatic by enrichment experiments. Thalassia Jugosl 13:13-24

Redfield AC (1958) The biological control of chemical factors in the environment. Am Sci 46:205-222

Ryther JH, Dunstan. WM (1971) Nitrogen, phosphorus and eutrophication in the coastal marine environment. Science 171:1008-1013

Sandén P, Rahm L, Wulff F (1991) Non-parametric trend test of Baltic Sea data. Environmetric 2:263-278

Schelske CL, Stoermer EF (1972) Phosphorus, silica and eutrophication of Lake Michigan. In: Likens GE (ed) Nutrients and eutrophication: the limiting-nutrient controversy. Allen Press, Inc, Lawrence, KS, p 157-171

Schöllhorn E, Granéli E (1996) Influence of different nitrogen to silica ratios and artificial mixing on the structure of a 
summer phytoplankton community from the Swedish west coast (Gullmar Fjord). Neth J Sea Res 35:159-167

Schöne HK, Schöne A (1982) A weakly enriched sea-water medium for ecological studies on marine plankton algae, some examples of its application. Bot Mar 25:117-122

Smayda TJ (1980) Phytoplankton species succession. In: Morris I (ed) The physiological ecology of phytoplankton. Studies in ecology, Vol 7. Blackwell, Oxford, p 493-570

Smayda TJ (1990) Novel and nuisance phytoplankton blooms in the sea: evidence for a global epidemic. In: Granéli E, Sundström B, Edler L, Anderson DM (eds) Toxic marine phytoplankton. Elsevier, New York, p 29-40

Smetacek V (1975) Die Sukzession des Phytoplankton in der westlichen Kieler Bucht. PhD thesis, Institut für Meereskunde, Kiel

Smith SV (1984) Phosphorus versus nitrogen limitation in the marine environment. Limnol Oceanogr 29:1149-1160

Sommer U (1983) Nutrient competition between phytoplankton species in multispecies chemostat experiments. Arch Hydrobiol 96:399-416

Sommer U (1988) Growth and survival strategies of planktonic diatoms. In: Sandgren CD (ed) Growth and reproductive strategies of freshwater phytoplankton. Cam-

Editorial responsibility: John Dolan,

Villefranche-sur-Mer, France bridge University Press, New York, p 227-260

Strathmann RR (1967) Estimating the organic carbon content of phytoplankton from cell volume or plasma volume. Limnol Oceanogr 12:411-418

Tilman D (1977) Resource competition between planktonic algae: an experimental and theoretical approach. Ecology 58:338-348

Turner JT, Tester PA, Lincoln JA, Carlsson P, Granéli E (1999) Effects of N:P:Si ratios and zooplankton grazing on phytoplankton communities in the northern Adriatic Sea. III Zooplankton populations and grazing. Aquat Microb Ecol 18:67-75

Utermöhl H (1958) Zur Vervollkommung der quantitativen Phytoplankton Methodik. Mitt Int Ver Limnol 9:1-38

Vollenweider RA, Rinaldi A, Montanari G (1992) Eutrophication, structure and dynamics of a marine coastal system: results of ten-year monitoring along the Emilia-Romagna coast (Northwest Adriatic Sea). In: Vollenweider RA, Marchetti R, Viviani R (eds) Marine coastal eutrophication. Elsevier, Amsterdam, p 63-106

Wulff F, Rahm L (1988) Long-term, seasonal and spatial variations of nitrogen, phosphorus and silicate in the Baltic: an overview. Mar Environ Res 26:19-37

Submitted: September 22, 1998; Accepted: October 29, 1998 Proofs received from author(s): July 12, 1999 